\title{
Przeszkoda katolicyzmu (impedimentum catholicismi) w prawie województw południowych II Rzeczypospolitej
}

W XIX w. przesłanki ważności małżeństwa przynajmniej częściowo wywodziły się z zasad religijnych. Prawo państwowe przewidywało przeszkody takie jak różność wiary czy święcenia kapłańskie. Małżeństwo zyskiwało przez to religijne oblicze. Pozostałe przesłanki nie wynikały jednak wprost z charakteru określonej doktryny religijnej. Przeszkody wieku lub pokrewieństwa nie mają ściśle religijnego podłoża. Impedimentum catholicismi nie mieści się jednak w tej grupie. Przeszkoda ta, podobnie jak przeszkoda różności wiary (disparitas cultus), wynikała wprost z zasad doktryny katolickiej.

Prawo małżeńskie obowiązujące w II Rzeczypospolitej pochodziło z okresu zaborów. Oblicze małżeństwa ukształtowane w ustawach pochodzących z tego okresu wynikało z charakteru byłych państw zaborczych, a w szczególności z ich stosunku do religii. Wyznaniowy charakter państwa przekładał się na kształt małżeństwa w prawie cywilnym. W Austrii i Rosji doszło do recepcji małżeńskiego prawa kościelnego. Natomiast w Prusach małżeństwo uzyskało świecki charakter. W konsekwencji w poszczególnych częściach odrodzonego państwa polskiego obowiązywały przepisy cechujące się różnym stosunkiem do małżeństwa wyznaniowego.

Po odzyskaniu niepodległości kwestia oceny ważności małżeństwa musiała uwzględniać stosunki międzydzielnicowe oraz wynikającą z konstytucji marcowej jednolitość państwa polskiego. SN stanął zatem na stanowisku, że ocena ważności małżeństwa powinna być dokonywana według prawa obowiązującego w miejscu jego zawarcia ${ }^{1}$. W orzecznictwie sądowym wyrażono także pogląd, że do osób zawierających małżeństwo w dzielnicy popruskiej nie miały zastosowania przeszkody religijne, zamieszczone w prawie obowiązującym w byłym Królestwie Kongresowym, chociażby osoby te zamieszkiwały na obszarze porosyjskim. Impedimentum disparitatis cultus nie brano zatem

\footnotetext{
${ }^{1}$ Wyrok ogólnego zgromadzenia SN z 10 XI 1923 r. (OSP III 149).
} 
pod uwagę przy ocenie ważności małżeństwa. W przypadku przeszkody katolicyzmu stanowisko wyrażone w orzecznictwie było jednak odmienne.

Przeszkoda katolicyzmu miała swoje uzasadnienie w zasadzie nierozwiązywalności małżeństwa katolickiego, która znalazła swoje odzwierciedlenie w prawie austriackim. Większość ziem polskich, które znalazły się w granicach II Rzeczypospolitej, była objęta regulacją uwzględniającą wyznaniowe przesłanki dopuszczalności rozwodu. Małżeństwo na obszarze byłego zaboru austriackiego regulowała powszechna księga ustaw cywilnych z $1811 \mathrm{r}$. Przepisy tej ustawy, w przeciwieństwie do przepisów obowiązujących na obszarze byłego zaboru rosyjskiego, przewidywały nieusuwalne bariery rozwodowe dla osób wyznania katolickiego. Pomimo że regulacja małżeństwa na obszarze obu byłych zaborów oparta była na kryterium wyznaniowym, prawo austriackie stwarzało zasadnicze przeszkody dla osób pragnących uzyskać rozwód. Konsekwencją tego stanu rzeczy było występujące w II Rzeczypospolitej zjawisko „wycieczek rozwodowych” do tej części państwa, w której rozwód był dopuszczalny. Mieszkańcy województw południowych często występowali z pozwem o rozwód do sądów konsystorskich w Warszawie lub Wilnie. Sądy te nie stosowały prawa byłego zaboru austriackiego i orzekały rozwód na podstawie przepisów obowiązujących w tej dzielnicy, w której miały siedzibę. Przeszkoda katolicyzmu dla osób, które skorzystały z tej możliwości uniemożliwiała jednak zawarcie kolejnego małżeństwa.

Przepisy o małżeństwie, obowiązujące w byłym zaborze austriackim, podobnie jak prawo Królestwa Kongresowego, cechowała odrębność norm materialnych dla członków poszczególnych wyznań. Prawo Królestwa Kongresowego wyróżniło pięć wyznań chrześcijańskich, regulując małżeństwo zawierane w każdym z nich w osobnym rozdziale. Małżeństwa w pozostałych wyznaniach chrześcijańskich uregulowano razem z małżeństwami niechrześcijańskimi. Regulacja małżeństwa w byłym zaborze austriackim przewidywała odrębne przepisy dla katolików, dla innych wyznań chrześcijańskich, dla Żydów i dla osób bezwyznaniowych ${ }^{2}$. Rozwód był dopuszczalny dla akatolików. Natomiast małżeństwo katolików nie mogło zostać rozwiązane. Porzucenie katolicyzmu przez jednego z małżonków nie miało wpływu na kwestię rozwiązania małżeństwa ${ }^{3}$.

Obydwa ustawodawstwa przyjęły także z prawa kanonicznego przeszkodę różności wiary (disparitas cultus). Przeszkoda ta uniemożliwiała zawarcie małżeństwa pomiędzy niechrześcijaninem a chrześcijaninem, którym w Austrii był członek każdego, także ustawowo nieuznanego, wyznania chrześcijańskiego ${ }^{4}$. Zatem prawo austriackie, tak jak i prawo Królestwa Kon-

${ }^{2}$ W. Jaworski, Prawo cywilne na ziemiach polskich, t. 1, Prawo matżeńskie, Warszawa 1917, s. $34-35$.

${ }^{3}$ J. Gwiazdomorski, Osobowe prawo matżeńskie, Poznań 1932, s. 61.

${ }^{4}$ W. Jaworski, Prawo cywilne na ziemiach polskich, t. 1, s. 88. 
gresowego, dokonało rozgraniczenia małżeństw chrześcijańskich i niechrześcijańskich. Prawo Kongresówki od nowelizacji w 1891 r. nie wyróżniało jednak małżeństwa katolickiego w takim stopniu jak prawo austriackie. Małżeństwo katolików w prawie austriackim było nierozwiązywalne za życia obu małżonków. Miarodajny w tej kwestii przepis $\S 111$ ABGB stanowił bowiem, że ważne malżeństwo między katolikami może być rozwiedzionem tylko przez śmierć jednego z malżonków. Podobnie nie może być rozwiazanem malżeństwo, jeżeli już w czasie jego zawarcia jedna chociażby tylko strona wyznawata religię katolicka ${ }^{5}$. Przepis ten znajdował zastosowanie także do małżeństw greko-katolików 6 .

S. Wróblewski wskazywał na związek § 111 z zasadą monogamii (§ 62). Skoro zatem według $\S 62 \mathrm{w}$ jednym czasie jeden mężczyzna $\mathrm{z}$ jedną niewiastą mogli pozostawać w małżeństwie, to - zdaniem S. Wróblewskiego - jeden małżonek dopiero po śmierci drugiego może zawrzeć nowe małżeństwo, a zawarty przedtem powtórny związek małżeński jest nieważny ${ }^{7}$. Z kolei zgodnie z § 119 rozwiedzionym malżonkom $w$ ogólności wolno jest wchodzić $w$ nowe zwiazki malżeńskie; jednakże nie może być zawarte ważnie malżeństwo z temi osobami, które wedlug dowodów w postępowaniu rozwodowym przedstawionych, przyczynity się do rozwodu przez cudzolóstwo, poduszczania lub innym karygodnem sposobem. Regulację powszechnej księgi ustaw cywilnych precyzowały dekrety kancelarii nadwornej z 1814 i 1835 r. S. Wróblewski podaje, że dekret nadworny z 26 sierpnia 1814 r. objaśniał przepis $\S 119 \mathrm{w}$ ten sposób, że w razie rozwodu niekatolickich wyznawców religii chrześcijańskiej, rozwiedzionym akatolikom wolno za życia drugiej rozwiedzionej strony zawrzeć ważne małżeństwo tylko $\mathrm{z}$ akatolikami, nie z tymi jednak, którzy według dowodów, przy rozwodzie przedłożonych spowodowali ten rozwód przez cudzołóstwo, przez poduszczania lub w inny karygodny sposób. Natomiast dekret z 17 lipca 1835 r. stwierdzał, że z tego objaśnienia kodeksu wynika samo przez się, że ważnego małżeństwa nie może zawrzeć strona katolicka z rozwiedzioną stroną akatolicką za życia rozwiedzionego drugiego małżonka; nie może też zawrzeć ważnego małżeństwa rozwiedziona $\mathrm{z}$ akatolikiem strona, która przy zawieraniu małżeństwa należała do religii akatolickiej, później jednak przeszła do Kościoła katolickiego, dopóki drugi rozwiedziony akatolicki małżonek żyje ${ }^{8}$.

Przeszkoda katolicyzmu miała złożony charakter, a poziom jej złożoności wzrastał w odniesieniu do małżeństw mieszanych, do których także znajdowała zastosowanie. Dużą rolę w określeniu zakresu jej zastosowania odgrywało orzecznictwo sądowe. Najpierw austriackie, a potem polskie, obej-

\footnotetext{
${ }^{5}$ W. Jaworski, Kodeks cywilny austryacki, t. I, Kraków 1903, s. 321.

${ }^{6}$ Ibidem.

${ }^{7}$ S. Wróblewski, Powszechny austryacki kodeks cywilny, cz. I, Kraków 1914, s. 54.

${ }^{8}$ Ibidem, s. 105.
} 
mujące dodatkowo komplikacje wynikające ze specyfiki stosunków międzydzielnicowych po odzyskaniu niepodległości. Prawo austriackie wykluczało rozwód małżeństwa zawartego między katolikami. Wpływu na tę zasadę nie miała późniejsza zmiana wyznania dokonana choćby przez oboje małżonków. W związku tą zasadą pozostawała przeszkoda katolicyzmu. Odnosiła się ona do małżeństwa zawieranego z rozwodnikiem. Decydującym kryterium jej zastosowania było przede wszystkim to, czy jednym z małżonków miał być katolik bez względu na to, czy planował on małżeństwo z drugim katolikiem, czy też z niekatolikiem. Kolejnym istotnym elementem konstrukcji tej przeszkody było to, że małżeństwo miało być zawarte z rozwodnikiem, którego były małżonek nadal pozostawał przy życiu. Przy czym oba elementy musiały wystąpić łącznie. Chodzi zatem o małżeństwo rozwodnika i katolika.

Wydaje się również, że charakterystyka przeszkody katolicyzmu wymaga rozróżnienia małżeństw mieszanych pierwotnie i wtórnie. Podział ten pozwala jednocześnie określić zakres dopuszczalności rozwodu. W prawie austriackim małżeństwa katolików z akatolikami podzielono na dwie grupy w zależności od tego, czy były od samego początku mieszanymi, czy też stały się nimi dopiero po zawarciu związku. Małżeństwo od początku mieszane nie mogło uzyskać rozwodu. Wystarczało zatem, aby przynajmniej jeden z małżonków w chwili zawierania związku był katolikiem, a małżeństwo było traktowane jak katolickie. Natomiast małżeństwo wtórnie mieszane, aby móc uzyskać rozwód, musiało mieć pierwotnie charakter jednolitego małżeństwa akatolików. Jeżeli więc małżeństwo było pierwotnie akatolickie, i stało się mieszanym w skutek przyjęcia przez jednego z małżonków katolicyzmu, to drugi małżonek mógł uzyskać rozwód i zawrzeć kolejne małżeństwo za życia swojego pierwszego małżonka. Nowe małżeństwo rozwiedziony akatolik mógł jednakże zawrzeć tylko $\mathrm{z}$ akatolikiem. $\mathrm{Z}$ kolei katolik, który się rozwiódł z akatolikiem, nie mógł za życia swojego byłego małżonka zawrzeć kolejnego małżeństwa. Akatolik miał zatem możność zawarcia nowego małżeństwa tylko z drugim akatolikiem. Katolik natomiast w ogóle nie miał takiej możliwości (poza przypadkiem śmierci byłego współmałżonka). W praktyce przeszkoda katolicyzmu oznaczała więc brak możliwości zawarcia małżeństwa z rozwiedzionym katolikiem ${ }^{9}$. Brak tej możliwości dotyczył także katolika, który planował małżeństwo z rozwodnikiem - niekatolikiem.

W uproszczeniu można stwierdzić, że przeszkoda katolicyzmu znajdowała zastosowanie w przypadku małżeństwa zawieranego przez rozwodnika z osobą wyznania katolickiego, przy czym chodziło o rozwodnika, którego były małżonek nadal pozostawał przy życiu. Przeszkoda ta dotyczyła zarówno katolika, który chciał zawrzeć małżeństwo z rozwiedzionym niekatolikiem za życia jego byłego małżonka, jak i osoby, która w trakcie zawierania mał-

${ }^{9}$ W. Jaworski, Prawo cywilne na ziemiach polskich, t. 1, s. 98- 99. 
żeństwa nie była katolikiem, później zaś przeszła na to wyznanie i uzyskała rozwód ze swoim współmałżonkiem niekatolickim. W tym przypadku nowe małżeństwo konwertyty było wykluczone, dopóki przy życiu pozostawał jego poprzedni małżonek ${ }^{10}$.

Międzywojenne orzecznictwo SN odnosiło się do przeszkody katolicyzmu wynikającej z przepisów austriackiej powszechnej księgi ustaw cywilnych (ABGB). Przeszkoda katolicyzmu miała w prawie austriackim charakter przeszkody zrywającej iuris publici. Nie odnoszono jej zatem tylko do osobistej zdolności do działania lub do prawnej zdolności woli nupturientów ${ }^{11}$. Przeszkoda katolicyzmu nie była jednak znana wyłącznie prawu austriackiemu. Podobne rozwiązanie przewidywało obowiązujące na obszarze Królestwa Kongresowego prawo małżeńskie z 1836 r. Konstrukcja tej przeszkody również oznaczała brak możliwości zawarcia kolejnego małżeństwa przez katolika po rozwodzie z małżonkiem akatolickim. Zawarcie małżeństwa w świątyni katolickiej wykluczało rozwód. Dotyczyło to również małżonka akatolickiego, jeżeli zawarł związek z katolikiem w świątyni jego wyznania (art. 197 PM). Rozwód był możliwy tylko wówczas, gdy małżeństwo zawarto wyłącznie w świątyni ewangelickiej (art. 196 PM). Był to oczywiście rozwód orzeczony w ewangelickim konsystorzu. Rozwód ten jednak z uwagi na przeszkodę katolicyzmu nie miał jednolitych skutków cywilnych względem obu małżonków. Nie pozwalał bowiem katolikowi na zawarcie małżeństwa nawet według obrządku ewangelickiego, podczas gdy jego były współmałżonek akatolicki mógł zawrzeć bez przeszkód kolejne małżeństwo ${ }^{12}$. Także rozwiązanie małżeństwa przez konsystorz prawosławny oznaczało dla osoby wyznania katolickiego niemożność zawarcia nowego związku, zanim sąd duchowny katolicki nie rozpatrzy sprawy jej poprzedniego małżeństwa (art. 204 PM). Ustawodawca określił więc sytuację prawną katolików w sposób korespondujący z unormowaniami kanonicznymi. Katolik, pomimo uzyskania rozwodu, w praktyce znajdował się w sytuacji małżonka separowanego.

Odrębną kwestią była regulacja art. 205 PM, która przewidywała brak możliwości rozwiązania małżeństwa zawartego przez katolików. Art. 205 PM dotyczył małżeństwa pierwotnie katolickiego, które stało się mieszanym wyznaniowo lub akatolickim. Niemniej, porzucenie katolicyzmu nawet przez oboje małżonków, którzy byli w momencie zawarcia małżeństwa katolikami,

${ }^{10}$ S. Wróblewski, Powszechny austryacki kodeks cywilny, cz. I, s. 105, podaje, że orzecznictwo austriackie odnosiło przeszkodę katolicyzmu także do przypadku, gdy rozwiedziona z bezwyznaniowym mężem żydówka przeszła przed ukończeniem postępowania rozwodowego na katolicyzm: jej małżeństwo za życia pierwszego małżonka było nieważne.

${ }^{11}$ W. Jaworski, Prawo cywilne na ziemiach polskich, t. 1, s. 145; idem, Kodeks cywilny austryacki, t. I, Kraków 1903, s. 165.

${ }^{12}$ H. Konic, Prawo matżeńskie obowiąujące w b. Królestwie Kongresowym,Warszawa 1924, s. 118. 
nie miało wpływu na właściwość sądu duchownego ${ }^{13}$. Przepis ten nie obejmował jednak wyznania prawosławnego. Tylko przejście na to wyznanie umożliwiało skuteczny cywilnie rozwód. Małżonek, który przyjął prawosławie, mógł wystąpić z pozwem rozwodowym do sądu swojego nowego wyznania.

W II Rzeczypospolitej powyższe rygory już nie obowiązywały. Władze rosyjskie w $1891 \mathrm{r}$. dokonały nowelizacji prawa małżeńskiego z $1836 \mathrm{r}$. W rezultacie wprowadzono zasadę jednakowego skutku rozwodu względem obojga małżonków ${ }^{14}$. Nowelizacja art. 196 PM wprowadziła w sprawie rozwodu ewangelickiego zasadę właściwości sądu wyznania pozwanego, co oznaczało, że konsystorz ewangelicki mógł orzekać rozwód obowiązujący pod względem cywilnym obu małżonków, jeżeli stroną pozwaną był ewangelik. Znowelizowany art. 204 PM również przewidywał, że wyrok rozwodowy konsystorza prawosławnego ma takie same skutki dla obu małżonków. Art. 197 i 205 PM zostały uchylone.

Po nowelizacji z 1891 r. prawo małżeńskie Królestwa Kongresowego w pewnych okolicznościach dopuszczało skuteczne pod względem cywilnym rozwody nawet dla katolików. Paradoksalnie więc prawo austriackie, chociaż przewidywało świecką jurysdykcję małżeńską, stwarzało więcej barier rozwodowych aniżeli prawo z 1836 r. Źródłem tego stanu rzeczy były różnice pomiędzy przepisami międzywyznaniowymi obu ustaw. Przepisy austriackie pozostawały pod większym wpływem doktryny katolickiej aniżeli prawo małżeńskie z 1836 r. „Stąd też - w ocenie SN - kodeks poaustriacki, stojący na stanowisku konfesyjnem, zgodnie z prawem kościelnem, stawia specjalne wymogi ważności małżeństwa, bo w tej instytucji upatruje szczególne walory podstawowego ustroju społeczeństwa i państwa” (Zb. Orz. 79/1932).

W. Jaworski był zdania, że prawo Królestwa Kongresowego przejęło z katolickiego prawa kanonicznego więcej przeszkód małżeńskich aniżeli prawo austriackie. Przeszkoda katolicyzmu pozwalała jednak na stwierdzenie, że w zakresie konfesyjności poszło prawo austriackie dalej aniżeli prawo Królestwa Kongresowego ${ }^{15}$. Z tego punktu widzenia niebagatelne znaczenie ma ocena skutków obowiązywania przeszkody katolicyzmu w nowych warunkach prawno-politycznych po odzyskaniu niepodległości. Istotne jest zatem ujęcie problematyki dotyczącej tej przeszkody w kontekście stosunków międzydzielnicowych w II Rzeczypospolitej. Przeszkoda ta była wówczas instytucją jednego $\mathrm{z}$ ustawodawstw dzielnicowych i wywierała wpływ na stosunki prawne w innych dzielnicach. Ten aspekt wydaje się także kluczowy dla oceny perturbacji w sferze prawno-rodzinnej po odzyskaniu niepodległości,

\footnotetext{
${ }^{13}$ Por. Ibidem, s. 196.

${ }^{14}$ Oznaczało to możliwość rozwiązania ze skutkiem cywilnym, obejmującym w takim samym stopniu obu małżonków, małżeństwa zawartego z katolikiem w Kościele katolickim oraz zawartego przez katolików w Kościele katolickim, jeżeli tylko jeden z nich zmienił następnie wyznanie.

${ }^{15}$ W. Jaworski, Prawo cywilne na ziemiach polskich, t. 1, s. 74-75.
} 
zwłaszcza że zamęt $\mathrm{w}$ tej sferze był tak wielki, że odcisnął swoje piętno na obliczu Polski doby międzywojnia i jest po dziś dzień przedmiotem licznych anegdot. Ukazanie roli przeszkody katolicyzmu wymaga przede wszystkim analizy orzecznictwa sądowego, które było wyznacznikiem jej oddziaływania na stosunki prawne w II Rzeczypospolitej. Oczywiście zadanie to w ramach niniejszych rozważań nie może zostać w pełni zrealizowane.

W II Rzeczypospolitej dla wielu osób wyznania katolickiego sposobem na obejście przeszkody katolicyzmu było uzyskanie rozwodu i zawarcie małżeństwa w tej części państwa, w której było to możliwe. Stało się to przyczyną wszczynania przez osoby zamieszkałe na obszarze byłego zaboru austriackiego procesów rozwodowych przed sądami konsystorialnymi w Warszawie. Sądy konsystorskie orzekały $\mathrm{w}$ takich przypadkach rozwód na podstawie przepisów prawa małżeńskiego z 1836 r. Orzeczenia te poprzedzała zmiana wyznania. Sytuacja ta przyczyniła się do sformułowania poglądu o negatywnej roli orzecznictwa konsystorskiego, podczas gdy rzeczywistą przyczyną zamętu w zakresie stosunków rodzinnych była przeszkoda katolicyzmu, zmuszająca obywateli zamieszkałych w południowej Polsce do ubiegania się o rozwód w sądach konsystorskich działających na obszarze byłego zaboru rosyjskiego.

Rozwód konsystorski w omawianym przypadku był skuteczny z uwagi na obowiązującą $\mathrm{w}$ stosunkach międzydzielnicowych zasadę równorzędności formalnej kodeksów, która była tak dalece posunięta, iż wykluczała zastosowanie ekscepcji porządku publicznego ${ }^{16}$. Rozwiązanie to, wobec obowiązywania w poszczególnych częściach Polski ustawodawstw byłych państw zaborczych, wychodziło naprzeciw zasadzie jednolitości państwa polskiego. Część przedstawicieli nauki prawa akceptowała tę praktykę. M. Allerhand podkreślił, że nie jest możliwe przenoszenie na stosunki międzydzielnicowe praktyk powszechnie stosowanych $\mathrm{w}$ stosunkach międzynarodowych, a w konsekwencji nie jest możliwe badanie kwestii jurysdykcji tej lub owej dzielnicy. W Polsce istniało bowiem jednolite orzecznictwo państwowe, a wobec sądów duchownych, które wykonują jurysdykcję w miejsce państwa, nie można stosować odmiennej zasady ${ }^{17}$. W tym samym kierunku idą także motywy wyroku ogólnego zgromadzenia SN z 10 XI 1923 r. (OSP III 149) ${ }^{18}$.

${ }^{16}$ T. Bujak, Z praktyki międzydzielnicowego prawa matżeńskiego, GSW z 22 XII 1923.

${ }^{17} \mathrm{M}$. Allerhand, O wptywie orzeczeń w sprawach matzeńskich wydawanych przez sady duchowne $w$ b. zaborze rosyjskim na stosunki prawne $w$ innych dzielnicach Rzeczypospolitej, PPA nr 4-6/1925, s. 122.

${ }^{18}$ SN stwierdził, że zasada legis patriae dominująca w stosunkach międzynarodowego prawa prywatnego, „nie może mieć zastosowania do stosunków międzydzielnicowych w obrębie RP, ponieważ nasza konstytucja... nie uznaje, poza województwem śląskiem, żadnych odrębności dzielnicowych, a i ustawa o obywatelstwie z 20 I 1920 r. dzu. poz. 44 zna tylko obywatelstwo państwa polskiego, niwecząc w ten sposób wszelkie pojęcia obywatelskiej przynależności dzielnicowej, jako pozostałość dawniejszej przynależności państwowej do państw zaborczych”. 
Orzecznictwo SN niejednokrotnie uznawało wyroki sądów konsystorskich za skuteczne na forum cywilnym, w całym państwie bez względu na stałe miejsce zamieszkania małżonków i na wyznanie rzymskokatolickie jednego z nich. W motywach orzeczenia Izby III SN z dnia 15 stycznia $1924 \mathrm{r}$. czytamy:

„mylne było rozstrzygnięcie sądu odwoławczego, wyrażające zapatrywanie prawne, że skoro oboje małżonkowie w chwili zawarcia małżeństwa byli katolikami, a $\S 111$ ustawy cywilnej w Małopolsce zniesiony nie został i nadal obowiązuje, przeto wyrok sądu konsystorskiego ewangelicko-reformowanego w Warszawie nie może mieć żadnego znaczenia dla niniejszego sporu i nie może mieć skutków prawnych na obszarze Małopolski" (OSP 147/1924) ${ }^{19}$.

Dopiero wejście w życie ustawy z dnia 2 sierpnia 1926 r. o prawie właściwem dla stosunków prywatnych wewnętrznych (Dz. U. RP Nr 101, poz. 580), określanej najczęściej mianem prawa prywatnego międzydzielnicowego, skomplikowało tę kwestię. Prawo to określiło właściwość prawa materialnego w sprawie rozwodowej, która zależna była od miejsca zamieszkania małżonków. SN, po wielu idących w przeciwnym kierunku orzeczeniach, ostatecznie wyraził $\mathrm{w}$ tej materii przekonanie, że przepisy art. 17 prawa prywatnego międzydzielnicowego ${ }^{20}$

„muszą być także przez sądy duchowne przestrzegane, jeżeli ich orzeczenia mają mieć znaczenie orzeczeń państwowych, gdyż ustawa z 2 VIII 1926 r. jest prawem późniejszym niż prawo o małżeństwie z r. 1836, a związki religijne nie mogą w myśl art. 113 Konstytucji stawać w sprzeczności z ustawami państwowemi..." $(\text { OSP XII 19) })^{21}$.

Zważyć jednak trzeba, że przedmiot regulacji prawa międzydzielnicowego nie miał związku z kompetencją sądu uregulowaną w dekrecie z $1836 \mathrm{r}$. Sąd konsystorski właściwy w sprawie rozwodowej zawsze stosował własne

${ }^{19}$ SN stał na stanowisku, że prawomocność wyroku konsystorskiego przesądza kwestię rozwiązania małżeństwa; wyrok musi być uznawany przez wszystkie sądy na terenie całego państwa. Zapatrywanie to pozostawało w zgodzie z $§ 411$ obowiązującej w byłym zaborze austriackim procedury cywilnej, w myśl którego prawomocność wyroku należy uwzględnić z urzędu.

${ }^{20}$ Osoba zamieszkała w byłym zaborze austriackim mogła według art. 17 ust. 2 żądać rozwodu w byłym Królestwie tylko wówczas, gdy był on dopuszczalny według prawa byłej Kongresówki i prawa poaustriackiego. Rozwód był możliwy na podstawie prawa, któremu małżonkowie osobiście podlegali w czasie żądania rozwodu, a gdy podlegali różnym prawom, według prawa ostatniego wspólnego zamieszkania (art. 17 ust. 1).

${ }^{21}$ SN uchwałą z 14 IX 1932 r. Rw. 1226/32 polecił, wpisać do księgi zasad prawnych, zasadę prawną, że wyrok sądu duchownego prawosławnego, orzekający rozwód małżeństwa, zawartego na ziemiach b. zab. austriackiego między osobami dawniej religii rzym.-kat., z których jedna następnie przeszła na prawosławie, nie jest skuteczny przeciwko małżonkowi, pozostającemu przy dawnej wierze, jeżeli ostatniem wspólnem prawem małżonków było prawo poaustriackie. 
przepisy wyznaniowe, tj. odnoszące się do niego w myśl prawa małżeńskiego z $1836 \mathrm{r}$.

M. Allerhand kwestionował orzecznictwo SN, wychodząc z założenia, że na gruncie art. $43 \mathrm{KPC}^{22}$, który wszedł w życie 1 stycznia 1933 r., zachodził przypadek, że sąd rozpoznawać będzie sprawę, w której należy stosować prawo innej dzielnicy ${ }^{23}$. W związku z tym, w sprawach małżonków, którzy wspólnie mieszkali w pewnej dzielnicy, mógł orzekać nie tylko sąd tej dzielnicy, ale także sąd konsystorski, gdyż przepis art. 43 odnosił się też do władz, które orzekały w miejsce sądów państwowych. Gdyby więc sąd konsystorski nie zastosował właściwego prawa materialnego, nie można by wyroku jego uznać za pozbawiony doniosłości ${ }^{24}$. Poglądowi temu odpowiada orzeczenie Izby III SN z dnia 14 maja 1930 r., w którym uznano skuteczność wyroku rozwodowego sądu konsystorskiego na obszarze całego państwa, pomimo niezastosowania przezeń prawa austriackiego, ale jednocześnie zakwestionowano małżeństwo zawarte po orzeczonym przez ten sąd rozwodzie z powodu przeszkody katolicyzmu (OSP X 129).

Przedmiotowe orzeczenie dotyczyło sporu co do nieważności małżeństwa zawartego z katoliczką na obszarze byłego zaboru austriackiego przez osobę, której pierwsze małżeństwo rozwiązał konsystorz kalwiński w Warszawie 15 września 1921 r. Decydujące było to, że osoba ta w czasie zawarcia pierwszego małżeństwa była wyznania katolickiego i podczas zawierania drugiego małżeństwa jej pierwszy małżonek nadal żył. W motywach orzeczenia stwierdza się, że w sprawie tej, wobec skuteczności rozwodu, nie można wprawdzie mówić o przeszkodzie dwużeństwa, ale nie wynika jeszcze, aby wskutek rozwiązania pierwszego małżeństwa, drugie tym samym miało być ważne. Drugiego dotyczyła bowiem przeszkoda katolicyzmu. Pozwany w sprawie o unieważnienie drugiego małżeństwa, w celu uzyskania rozwodu z pierwszą żoną porzucił katolicyzm i przyjął kalwinizm. Po rozwodzie zawarł małżeństwo z katoliczką, która zakwestionowała związek z powodu pozostawania przy życiu pierwszej żony. Fakt ten sprawiał, że kolejne małżeństwo nie mogło zostać ważnie zawarte z katoliczką, a zamieszkujący w byłym Królestwie Kon-

${ }^{22}$ W sprawie właściwości miejscowej sądu art. 43 KPC stanowił: „,powództwo ze stosunku małżeństwa, jeżeli przynajmniej jedna ze stron ma obywatelstwo polskie, wytoczyć należy według miejsca ostatniego wspólnego zamieszkania w Polsce, gdy choć jedno z małżonków w tem miejscu stale przebywa; w braku zaś tych podstaw do zapozwania powództwo wytoczyć należy według miejsca pobytu strony pozwanej, a gdy niema i tej podstawy - według zamieszkania powoda”.

${ }^{23}$ M. Allerhand, Jurysdykcja władz wyznaniowych w sprawach matżeńskich, odbitka z „Czasopisma Sędziowskiego”, Rocznik XI. Nr 3 i 4 z r. 1937, Lwów 1937, s. 19, wskazuje, że przypadku, gdy ,żaden z małżonków, którzy mieszkali razem na obszarze prawa austriackiego, nie przebywał stale w miejscu ostatniego wspólnego zamieszkania, to wytoczenie powództwa w b. zab. ros. uznać należy jako możliwe, jeżeli tylko jeden z nich tamże przebywa”.

${ }_{24}$ M. Allerhand, Miejscowa właściwość sądu dla spraw ze stosunku matżeństwa, odbitka z „Polskiego Procesu Cywilnego”, s. 21-22. 
gresowym pozwany małżonek-konwertyta mógł w świetle prawa dzielnicy poaustriackiej zawrzeć małżeństwo jedynie z akatoliczką. Przeszkoda katolicyzmu stała się więc $\mathrm{w}$ niniejszej sprawie wystarczającą podstawą nieważności małżeństwa, niezależnie od skuteczności cywilnoprawnej rozwodu konsystorskiego. Problemem w tej sprawie nie były zresztą kontrowersje dotyczące jurysdykcji sądu konsystorskiego, ale zawarcie małżeństwa z katoliczką przez byłego katolika, który rozwiódł się z pierwszą żoną po zmianie wyznania. Do osoby tej zatem znalazła zastosowanie przeszkoda katolicyzmu, chociaż nie zamieszkiwała ona na obszarze byłego zaboru austriackiego.

Zawarcie małżeństwa na obszarze byłego zaboru austriackiego przez rozwodnika z osobą wyznania katolickiego było zakazane. Odpowiadało bowiem treści przeszkody katolicyzmu. Natomiast ewentualna nieskuteczność rozwodu pierwszego małżeństwa stanowiła odrębne zagadnienie. Wynikająca bowiem z tej nieskuteczności kwestia bigamicznego charakteru kolejnego małżeństwa nie wpływała na przeszkodę katolicyzmu. Z punktu widzenia konstrukcji normatywnej przeszkoda katolicyzmu była niejako przeciwieństwem bigamii. Dla jej wystąpienia decydujące było bowiem nie trwanie pierwszego małżeństwa, ale pozostawanie przy życiu pierwszego małżonka. Nieskuteczność rozwodu prowadziła wprawdzie do powstania kolejnego tytułu nieważności małżeństwa - bigamii. Nie miało to jednak wpływu na generalny zakaz zawarcia małżeństwa w prawie austriackim, obowiązujący katolika i rozwodnika, którego były małżonek pozostaje przy życiu.

W orzecznictwie SN powyższe czynniki brane były pod uwagę bez względu na to, czy rozwód nastąpił w Polsce i czy rozwodnik był obywatelem polskim. Orzeczenie Izby III SN z dnia 7 stycznia 1931 r. dotyczyło nieważności małżeństwa zawartego w dniu 4 lutego 1922 r. we Lwowie przez obywatelkę polską religii rzymskokatolickiej z rozwiedzionym obywatelem czechosłowackim, także religii rzymskokatolickiej (OSP XII 18). Czech zawarł pierwsze małżeństwo ze swoją rodaczką w Czechosłowacji. Tam też uzyskał separację i rozwód orzeczony wyrokiem sądu obwodowego w Pilźnie dnia 7 X 1921 r. Sądy polskie dzielnicy poaustriackiej stanęły na stanowisku nieważności drugiego małżeństwa, z tą jedynie różnicą, że sąd apelacyjny w przeciwieństwie do sądu okręgowego, uwzględnił czeski wyrok rozwodowy i przez to uznał, że drugie małżeństwo nie jest bigamiczne. Nie miało to jednak wpływu na wynik sprawy, wobec istnienia przeszkody katolicyzmu.

SN nie uwzględnił rewizji, podzielając jednak pogląd, że Czech po uzyskaniu rozwodu nabył zdolność do zawarcia ponownego małżeństwa w swojej ojczyźnie. Następnie SN stwierdził:

„Nie wynika z tego jednak, aby osoba z którą pozwany wchodzi w związek małżeński zwolniona była od zastosowania się przy zawarciu małżeństwa do tych przepisów, którym ona osobiście podlega. Powódka, będąc katoliczką i obywa- 
telką polską, zamieszkałą na terenie b. zaboru austrjackiego, podlegała w czasie zawarcia spornego małżeństwa przepisom § 111 kod. cyw., według których katolik nie może zawrzeć ważnego związku małżeńskiego z katolikiem, jak długo współmałżonek tego katolika żyje”.

Rozwodnicy byli najczęściej konwertytami zamieszkującymi w byłym zaborze rosyjskim, którzy uzyskali rozwód w sądzie konsystorskim. Oto kolejny przykład takiego stanu faktycznego. W orzeczeniu Izby III SN z 15 marca 1927 r. zakresem przeszkody katolicyzmu objęto małżeństwo z rozwodnikiem wyznania ewangelickiego (OSP VI 315). SN stwierdził, że katolik z byłej dzielnicy austriackiej nie może zawrzeć ważnego małżeństwa z rozwiedzioną ewangeliczką z byłego Królestwa Kongresowego. Powód zamieszkiwał w dzielnicy poaustriackiej, pozwana zaś w byłej Kongresówce, gdzie jako katoliczka zawarła pierwsze małżeństwo z katolikiem. Małżeństwo to zostało rozwiązane po uprzednim przejściu pozwanej na kalwinizm. Powód zawarł następnie małżeństwo z pozwaną w Warszawie w 1922 r., gdy jej pierwszy mąż nadal żył. M. Allerhand w glosie do niniejszego orzeczenia zaznaczył, że

„mylnem zaś byłoby oceniać ważność małżeństwa tylko według prawa obowiązującego w miejscu zawarcia, bo tej zasady nie uznawało prawo austriackie”.

Małżeństwo rozwódki wyznania ewangelickiego z katolikiem było w świetle obowiązującego w centralnej Polsce prawa małżeńskiego z 1836 r. ważne, było jednak nieważne w świetle prawa dzielnicy poaustriackiej, któremu podlegał osobiście jej małżonek wyznania katolickiego. Katolik bowiem - stwierdził następnie M. Allerhand - nie tylko wtedy nie może wejść w ważny związek małżeński z osobą rozwiedzioną, której poprzedni małżonek żyje, gdy ta rozwiedziona osoba również podlega prawu austriackiemu, lecz i wtedy, gdy jest obcokrajowcem lub podlega prawu obowiązującemu w innej dzielnicy; rozwiedziona osoba może zawrzeć ważne małżeństwo z osobą podlegającą prawu austriackiemu tylko wtedy, gdy ta osoba nie jest katolikiem ${ }^{25}$.

Problem właściwości prawa materialnego nie budził wątpliwości dla żadnego z orzekających w toku instancji sądów. Małżeństwo zawarto wprawdzie przed wejściem w życie prawa międzydzielnicowego, jednak także i wtedy obowiązywała w byłym zaborze austriackim zasada przynależności gminnej, która prowadziła do analogicznych skutków w zakresie właściwości prawa materialnego, powód zaś należał do gminy na obszarze dzielnicy poaustriackiej $^{26}$. Przeszkoda katolicyzmu znajdowała zatem do niego zastosowanie, bo pozwana, posiadając zdolność do zawarcia małżeństwa w świetle prawa województw centralnych, mogła zawrzeć nowe małżeństwo, ale nie z katolikiem

${ }^{25}$ M. Allerhand, Glosa do orzeczenia Izby III SN z 15 marca 1927 r. OSP 315.

${ }^{26} \mathrm{M}$. Allerhand, w glosie do niniejszego orzeczenia, podziela to stanowisko. 
osobiście podlegającym prawu austriackiemu. W konsekwencji należy stwierdzić, że katolik w świetle prawa austriackiego mógłby zawrzeć małżeństwo z pozwaną tylko wówczas, gdyby ta była panną, wdową lub rozwódką, której były małżonek już nie żyje.

Rozwód konsystorski w Warszawie pozostawał często jedynym wyjściem dla skonfliktowanych małżonków z byłego zaboru austriackiego. Jednak SN ostatecznie uznał, że sądy konsystorskie muszą przestrzegać prawa międzydzielnicowego. Uznawanie bowiem wyroków zapadłych z jego naruszeniem „równałoby się zupełnemu niemal uchyleniu w tej materji ustaw dzielnicowych" (Zb. Orz. 124/1934). Zmiana linii orzecznictwa SN nie nastąpiła jednak natychmiast. Jeszcze w latach trzydziestych SN uznawał, że wyroki Warszawsko-Chełmskiego Konsystorza Prawosławnego mają moc obowiązującą w całym państwie bez względu na miejsce zamieszkania małżonków i wyznanie rzymskokatolickie jednego z nich. SN traktował orzeczenia konsystorza prawosławnego na równi z orzeczeniami sądu państwowego, co skutkowało przyjęciem zasady, że orzeczenia konsystorskiego po jego prawomocności nie można badać pod kątem, czy sąd, od którego pochodzi to orzeczenie, posiadał właściwość do zajęcia się sprawą.

Po zmianie stanowiska w orzecznictwie SN prezentowany był pogląd o nieważności małżeństwa zawartego po rozwodzie w sądzie kościelnym działającym na obszarze byłego zaboru rosyjskiego. W każdym bowiem przypadku był to sąd, który nie zastosował prawa, któremu małżonkowie podlegali osobiście. W rezultacie, do konsekwencji wynikających z przeszkody katolicyzmu doszła kwestia dwużeństwa, rozwód konsystorski bowiem pozbawiony był w powyższym przypadku skutków cywilnych.

SN w orzeczeniu z dnia 19 lipca 1933 r. stwierdził, że pod rządem prawa małżeńskiego obowiązującego na ziemiach południowych, osoba, która w czasie zawarcia małżeństwa była katoliczką, nie ma możności prawnego wstąpienia w związek małżeński, dopóki jej współmałżonek żyje, chociażby przeszła na inną religię, a sąd duchowny jej nowego wyznania udzielił jej rozwodu (OSP XIII 335) ${ }^{27}$. Kluczowym czynnikiem w tej sprawie był fakt, że pierwszy mąż nadal żył i nie zaszły warunki art. 2, 3 i 13 prawa międzydzielnicowego prowadzące do zmiany prawa właściwego w sprawie rozwodowej.

${ }^{27} \mathrm{~W}$ tym przypadku chodziło o małżonków, którzy zamieszkiwali na obszarze zaboru austriackiego i tam też zawarli małżeństwo, które następnie zostało separowane wyrokiem sądu okręgowego w Krakowie 21 listopada 1921 r. Separowana żona uzyskała następnie rozwód w wileńskim konsystorzu kalwińskim i 20 lutego 1927 r. zawarła kolejne małżeństwo w krakowskim Kościele ewangelickim również z mieszkańcem byłego zaboru austriackiego. Nowy mąż porzucił katolicyzm i w dniu ślubu przyjął wyznanie ewangelickie. Nowy mąż wystąpił o unieważnienie tego małżeństwa, które uzyskał wyrokiem sądu okręgowego z 29 września 1932 r. W wyroku tym uznano drugie małżeństwo za nieważne i przyjęto, że konsystorz wileński był nieuprawniony do orzeczenia rozwodu, bo pierwsze małżeństwo podlegało prawu austriackiemu. Sąd apelacyjny podzielił to stanowisko. 
Przepisy te uzależniały możność zawarcia małżeństwa od zgodności z prawem miejsca zamieszkania każdego z nupturientów, a ponadto dopuszczały ocenę tej kwestii pod kątem lex loci celebrationis matrimonii ${ }^{28}$. W konsekwencji małżeństwo, które rozwiązał konsystorz wileński, było zawarte przez osoby podlegające osobiście prawu austriackiemu, które wykluczało rozwód małżeństwa zawartego przez katolików ${ }^{29}$. Nowe małżeństwo było nieważne, bo możność zawarcia ważnego małżeństwa oceniało się według prawa, któremu każda ze stron podlegała osobiście. Małżeństwo to zawierały osoby podlegające osobiście prawu austriackiemu. Tym samym zastosowanie znalazła przeszkoda katolicyzmu, której zakres wyznaczyło wyznanie katolickie przynajmniej jednej z osób zawierających małżeństwo.

Niezależnie od regulacji prawa międzydzielnicowego, poruszona $\mathrm{w}$ orzecznictwie kwestia podlegania prawu austriackiemu, wynikała z $\S 4$ ABGB, stanowiącego, że ustawy cywilne obowiazuja wszystkich obywateli państwa w krajach, dla których je ogłoszono. Obywatele państwa sa zwiqzani temi ustawami także w czynnościach i aktach, które przedsiębiora poza terytorjum państwa, o ile te ustawy ograniczaja ich osobista zdolność do przedsiębrania tych czynności i aktów i o ile te czynności i akta maja zarazem w tych krajach wywolać prawne skutki. Przepisowi temu obywatel austriacki podlegał także przy zawieraniu małżeństwa za granicą ${ }^{30}$. W orzecznictwie austriackim wskazywano, że prawo obce znajdowało zastosowanie co do formy. Małżeństwo obywatela austriackiego zawarte z cudzoziemką za granicą wedle obowiązującej w miejscu zawarcia formy było ważne ( $§ 4$ i 37 ABGB). Również małżeństwo obywateli austriackich wyznania katolickiego zawarte w Rumunii było ważne, pomimo zastosowania formy świeckiej, wymaganej przez rumuński kodeks cywilny ${ }^{31}$. Po odzyskaniu niepodległości w wyroku

${ }^{28}$ Art. 2: Kto zmienia miejsce zamieszkania, ten $w$ dziedzinie zdolności osobistej, stosunków familijnych i praw spadkowych podlega prawu nowego miejsca zamieszkania dopiero po jednym roku; art. 3 ust. 1: Miejscem zamieszkania wedlug ustawy niniejszej jest miejsce na obszarze Polski, gdzie obywatel polski mieszka z zamiarem stałego pobytu. Jeżeli ma kilka miejsc zamieszkaniawłaściwe jest prawo miejsca, w którem skupia się główny i przeważający zakres jego działalności. Obywatel polski, mieszkajacy za granica, podlega prawu obowiązujacemu w ostatniem miejscu zamieszkania $w$ Polsce. Jeżeli w ogóle zamieszkania w Polsce nie da się ustalić, właściwe jest prawo, obowiązujace w stolicy państwa; art. 3 ust. 2: Mężatka sądownie nie rozłaczona idzie co do miejsca zamieszkania za mężem; nieletnie lub niewłasnowolne dzieci ślubne, uprawnione (legitymowane) i przysposobione (adoptowane) ida za ojcem, nieślubne za matką. Jeżeli mąż mieszka zagranica, a żona i dzieci pozostały w Polsce - wlaściwe jest dla nich prawo miejsca ich stałego pobytu; art. 13 ust. 1: Prawna możność zawarcia ważnego zwiąku matżeńskiego ocenia się dla każdej ze stron wedlug prawa, któremu strona podlega osobiście (art. 1 i 2); art. 13 ust. 2: Władza właściwa może odmówić udzielenia ślubu obywatelowi polskiemu, zdolnemu do zawarcia matżeństwa wedlug prawa, któremu podlega osobiście, gdyby byl niezdolny wedlug prawa, obowiazującego w siedzibie władzy.

29 W sprawie rozwodów orzekanych w Wilnie szerzej: W. Sygierycz, O tak zwanych rozwodach wileńskich, „Przegląd Sądowy” nr 3 III 1930.

${ }^{30}$ W. Jaworski, Kodeks cywilny austryacki, t. I, s. 266.

${ }^{31}$ Ibidem, s. 165. 
ogólnego zgromadzenia SN z 10 XI 1923 r. (OSP III 149) przyjęto, że o ważności małżeństwa rozstrzyga prawo miejsca jego zawarcia (locus regit actum). W orzecznictwie sądowym aprobowano zatem pogląd, że w stosunkach międzydzielnicowych, z uwagi na jednolitość państwa, każdy akt zdziałany zgodnie z prawem jednej dzielnicy musi być uznany za ważny w całej Polsce. Państwo bowiem, uznając ustawy o rozmaitych zasadach, przyjmuje tym samym, że żadna $\mathrm{z}$ nich nie sprzeciwia się ani dobrym obyczajom, ani porządkowi publicznemu. Ostatecznie jednak przeważył w orzecznictwie pogląd, że prawo poaustriackie obowiązywało obywatela polskiego zamieszkałego na terenie byłego zaboru austriackiego, zawierającego małżeństwo w innej dzielnicy Polski. Rozwodnik mógł zatem zawrzeć małżeństwo tylko wówczas, gdy jego były małżonek nie żył albo gdy jego nowy małżonek nie był katolikiem.

Orzecznictwo sądowe, kwestionując skutki cywilne wyroków rozwodowych, jednocześnie akcentowało sprzeczność małżeństw zawartych z przeszkodą katolicyzmu, która w oparciu o przepisy prawa międzydzielnicowego musiała zostać uwzględniona, jeżeli przynajmniej jeden z współmałżonków podlegał prawu austriackiemu. Paradoksalnie, to jednak prawo międzydzielnicowe umożliwiło obejście tej przeszkody, postanawiając w art. 2, że zmiana prawa, któremu osobiście się podlega, następuje po rocznym zamieszkiwaniu w innej dzielnicy państwa. W konsekwencji, po roku zamieszkiwania w dzielnicy popruskiej lub w byłym Królestwie Kongresowym zawarcie kolejnego małżeństwa byłoby możliwe. Warunkiem jego skuteczności było to, aby współmałżonek nie podlegał osobiście prawu austriackiemu.

Zakres przeszkody katolicyzmu był dość szeroki. Przeszkoda katolicyzmu znajdowała zastosowanie zarówno, gdy rozwodnikiem był katolik, jak i akatolik, i to niezależnie od tego, czy podlegał on osobiście prawu austriackiemu, czy też prawu temu podlegała osoba, z którą zawierał małżeństwo. W grę wchodziła wiec sytuacja, gdy rozwodnik w świetle swojego prawa ojczystego (gdy obywatel polski zawierał małżeństwo z cudzoziemcem) bądź prawa dzielnicowego, któremu osobiście podlegał, miał zdolność do zawarcia małżeństwa, ale zawarcie małżeństwa było niemożliwe z uwagi na wyznanie katolickie kandydata na nowego małżonka i, ponadto, pozostawanie przy życiu poprzedniego małżonka.

Przeszkoda katolicyzmu uniemożliwiała zawarcie małżeństwa przez katolika z rozwodnikiem, jak długo żyje jego były małżonek. Wystarczyło tylko, aby którykolwiek z nich podlegał prawu austriackiemu. Katolicy zamieszkali w południowej Polsce mogli poprzez zmianę wyznania uzyskać rozwód w byłym zaborze rosyjskim. Przeszkoda katolicyzmu uniemożliwiała tym osobom zawarcie kolejnego małżeństwa. Wykluczała też zawarcie małżeństwa przez rozwiedzionego cudzoziemca $\mathrm{z}$ obywatelem polskim wyznania katolickiego, jeżeli podlegał on prawu austriackiemu. 
Po odzyskaniu niepodległości kwestią sporną, w kontekście określenia właściwości miejscowej sądu $\mathrm{w}$ sprawie małżeńskiej z elementem międzydzielnicowym, była wykładnia użytego w $§ 99$ Normy jurysdykcyjnej wyrazu „kraj” (OSP III 185). Mianowicie: czy oznaczał on obszar byłego zaboru austriackiego, czy też cały obszar Polski. Pierwsze rozwiązanie zaprezentowano w orzecznictwie Izby III SN ${ }^{32}$. Drugie stanowisko zyskało jednak uznanie M. Allerhanda ${ }^{33}$. Przez odnoszenie wyrazu „kraj” do obszaru dzielnicy poaustriackiej zyskiwała na znaczeniu tzw. przynależność dzielnicowa obywateli.

W zakresie stosunków międzydzielnicowych uchylenie zastosowania przeszkody katolicyzmu stało się możliwe po wejściu w życie prawa międzydzielnicowego, które uregulowało kwestię zmiany właściwości prawa materialnego II Rzeczypospolitej. Zmiana ta nie mogła być zatem traktowana jako próba obejścia przeszkody katolicyzmu, aczkolwiek niewątpliwie taka motywacja osobom korzystającym z tej możliwości przyświecała. Do osiągnięcia tego celu wystarczał roczny pobyt w innej dzielnicy państwa aniżeli były zabór austriacki. Skutku takiego nie miał rozwód zagraniczny ${ }^{34}$. SN uznał, że rozwód zawartego w kraju małżeństwa katolików przed sądem amerykańskim, podlegających osobiście prawu dzielnicy proaustriackiej, jest bezskuteczny w Polsce. Dla rozwodu, jeżeli skutki jego miały się ujawnić w kraju, właściwe były władze tutejsze i prawa w kraju obowiązujące, skoro małżeństwo tu było zawarte. Również obojętną jest rzeczą, gdzie strony w chwili żądania rozwodu mieszkały ( $\S 4$ i 111). Prawo amerykańskie nie mogło stanowić podstawy oceny skuteczności rozwodu, ponieważ strony były w czasie żądania rozwodu (1911 r.) przynależne w państwie austriackim, gdzie obowiązywał wzmiankowany $\S 111$, a przynajmniej obywatelką austriacką była powódka i bez znaczenia była podniesiona dopiero w odwołaniu okoliczność, że pozwany jest obywatelem amerykańskim (OSP IX 312$)^{35}$.

${ }^{32}$ W orzeczeniu Izby III SN z 23 stycznia 1924 r. zajęto stanowisko, że przez wyraz „kraj” (Inland) w § 99 n.j. (art. X ust. wpr. do n.j.), rozumieć należy ten obszar Rzplitej Polskiej, na którym obowiązuje norma jurysdykcyjna z 1 sierpnia $1895 \ldots$, a więc cztery województwa południowe i cieszyńską część województwa śląskiego (OSP III 318).

${ }^{33}$ M. Allerhand, Glosa do orzeczenia SN z 10 X 1923 r. OSP III 185 oraz Glosa do orzeczenia z 23 I 1924 r. OSP III 318.

${ }^{34}$ S. Wróblewski, Powszechny austryacki kodeks cywilny, s. 96-97, podaje, że według stanowiska orzecznictwa austriackiego obojętną była okoliczność, iż poddany austr. uzyskał zagranicą na podstawie prawa obcego rozwód: wobec prawa austr. rozwód ten, choćby uzyskany drogą prawomocnego wyroku zagranicznego, jest bez znaczenia, gdyż dla poddanych austr. rozwód orzec może ze skutkiem prawnym tylko sąd austr. Wobec prawa austr. zatem taki rozwiedziony zagranicą małżonek pozostaje nadal - póki druga strona żyje - związany węzłem małżeńskim i nie może, dopóki ta przeszkoda istnieje, zawrzeć ważnie innego małżeństwa. Obojętne jest przy tym, czy zawierając (pierwsze) małżeństwo był katolikiem, czy akatolikiem, a w pierwszym przypadku obojętną jest również późniejsza zmiana wyznania religijnego.

35 S. Wróblewski, Powszechny austryacki kodeks cywilny, s. 97, omawia ewolucję orzecznictwa austriackiego odnoszącą się do kwestii związania przeszkodą katolicyzmu poddanego austriackiego, który zmienił obywatelstwo. 
W orzecznictwie austriackim $\S 4$ ABGB tłumaczono w ten sposób, że to co obywatelowi austriackiemu zakazane jest w kraju, nie może być przez niego przedsięwzięte i za granicą, ze skutkiem prawnym mającym się ujawnić w kraju ${ }^{36}$. Zasada ta dotyczyła nie tylko zawarcia małżeństwa za granica, ale także rozwodu. Nie było więc możliwe zawarcie małżeństwa za granicą z rozwodnikiem przez katolika podlegającego prawu austriackiemu. Wykluczony był również rozwód za granicą małżeństwa katolików podlegających temu prawu. Nierozwiązywalność małżeństwa zawartego przez katolika była zatem punktem wyjścia w kwestii zastosowania przeszkody katolicyzmu. S. Wróblewski podkreślał, że nie miało znaczenia, czy małżeństwo było zawarte w Austrii w formie wyznaniowej lub świeckiej, czy za granicą. Istotne było tylko to, czy było to małżeństwo, o którym mowa w $\S 111$ (z udziałem osoby wyznania katolickiego) ${ }^{37}$. W konsekwencji obywatel austriacki, a następnie polski, ale zamieszkały w byłym zaborze austriackim, musiał brać pod uwagę przeszkodę katolicyzmu także wówczas, gdy planował za granicą małżeństwo $\mathrm{z}$ rozwódką ${ }^{38}$.

Po odzyskaniu niepodległości pojawiła się kwestia konstytucyjności przeszkody katolicyzmu. M. Allerhand uważał, że wprowadzenie osobnych przepisów małżeńskich do członków poszczególnych wyznań nie stanowi jeszcze nierówności obywateli wobec prawa ${ }^{39}$. Przeszkoda katolicyzmu nie daje się jednak pogodzić z zasadą wolności sumienia i wyznania (art. 111 konstytucji). Utrzymanie w mocy przeszkody katolicyzmu wynikało z przyjętej po odzyskaniu niepodległości strategii dostosowania prawa małżeńskiego do konstytucji marcowej. Miała ona polegać na całościowym rozwiązaniu powyższej kwestii w ramach ogólnopaństwowej unifikacji prawa małżeńskiego. Projekt Komisji Kodyfikacyjnej z 1929 r. został jednak zarzucony przez dyktaturę sanacyjną, gdyż spotkał się z ostrą krytyką środowisk katolickich. W rezultacie przeszkoda katolicyzmu obowiązywała przez cały okres istnienia II Rzeczypospolitej.

Przeszkoda katolicyzmu w Polsce międzywojennej wywierała wpływ na stosunki prawne w sposób, który miał swoją specyfikę z uwagi na charakter obowiązującego systemu prawnego. Polska była państwem o niejednolitym systemie prawnym. W poszczególnych jej częściach obowiązywały ustawodawstwa byłych państw zaborczych. Przeszkoda katolicyzmu obowiązywała tylko w tej części Polski, która uprzednio należała do Austrii. W konsekwencji skutki obowiązywania przeszkody katolicyzmu kształtowały stosunki między-

${ }^{36}$ W. Jaworski, Kodeks cywilny austryacki, t. I, s. 266.

${ }^{37}$ S. Wróblewski, Powszechny austryacki kodeks cywilny, cz. I, s. 96.

${ }^{38}$ Ibidem, s. 105, Wróblewski podaje, że przeszkoda katolicyzmu wiązała poddanych austriackich przy małżeństwach zawieranych za granicą i mających wywołać skutki prawne w Austrii, i to bez względu na to, że rozwód cudzoziemskiego narzeczonego był prawidłowy.

${ }^{39}$ M. Allerhand, Glosa do orzeczenia Izby III SN z 15 marca 1927 r. OSP 315. 
dzielnicowe, prowadząc do zamieszania w sferze prawno-rodzinnej. Ograniczenie dopuszczalności rozwodu dla katolików w prawie austriackim skutkowało tzw. wycieczkami rozwodowymi do tej części państwa, w której rozwód był możliwy. Jednakże małżeństwa zawarte po uzyskaniu rozwodu były z uwagi na przeszkodę katolicyzmu nieważne. Na tym tle doszło z kolei do konfliktów wyznaniowych, wycieczki miały bowiem na celu uzyskanie rozwodu w niekatolickich sądach konsystorialnych. Nowe małżeństwa często zawierano w innym wyznaniu. W rezultacie ataki prasy prokatolickiej oraz sprzyjającej jej administracji państwowej skupiły się na niekatolickich konsystorzach. To ich orzecznictwo miało anarchizować stosunki prawne w Polsce, prowadząc do bigamii, zalegalizowanej bezprawnym rozwodem. Pogląd ten pokutuje w literaturze przedmiotu po dziś dzień. Na dalszy plan schodzi natomiast rzeczywista przyczyna tzw. legalnej bigamii, jak nazwał to zjawisko w międzywojennej Polsce H. Świątkowski. W okresie tym kluczowym problemem była bowiem sprzeczność ustawodawstw dzielnicowych. W szczególności chodzi tu o ustawodawstwo byłego zaboru rosyjskiego i austriackiego. Paradoksalnie, oba ustawodawstwa uznawały religijny walor małżeństwa. W konsekwencji oba zawierały także przepisy międzywyznaniowe dotyczące małżeństw mieszanych. Niestety, przepisy te pozostawały ze sobą w sprzeczności. Prawo byłej Kongresówki nie przewidywało nierozwiązywalności małżeństwa katolickiego jako zasady bezwzględnie obowiązującej. Małżeństwo z katolikiem mogło zostać rozwiązane niezależnie od tego, czy było pierwotnie, czy wtórnie mieszane, jeżeli tylko pozwanym w sprawie rozwodowej był niekatolik (art. 196 PM). Takiej możliwości nie przewidywało prawo międzywyznaniowe powszechnej księgi ustaw cywilnych. Była to zatem kolizja nieusuwalna.

Z powyższych rozważań wyłaniają się dwa aspekty związane z obowiązywaniem przeszkody katolicyzmu po odzyskaniu niepodległości. $Z$ jednej strony kwestia skuteczności rozwodu orzeczonego w innej dzielnicy względem katolików zamieszkałych w byłym zaborze austriackim, z drugiej strony kwestia dopuszczalności nowego małżeństwa dla tych osób. Pierwsza kwestia wiązała się z oceną jurysdykcji sądu konsystorskiego. Ocena ta podlegała ewolucji. Orzecznictwo sądowe ostatecznie opowiedziało się jednak za brakiem skuteczności rozwodu orzeczonego w innej dzielnicy, co jednocześnie przesądzało o bezprzedmiotowości drugiej kwestii, bo skoro istnieje pierwsze małżeństwo, zawarcie drugiego oznacza bigamię. Należy jednak zauważyć, że zanim pierwsza kwestia została rozstrzygnięta w powyższy sposób, orzecznictwo stało na stanowisku nieważności małżeństwa zawartego po rozwodzie konsystorskim z powodu przeszkody katolicyzmu. W tym wypadku nie chodziło więc o małżeństwo bigamiczne, ale o małżeństwo nieważne tylko z tytułu przeszkody katolicyzmu.

Problematyka przeszkody katolicyzmu w wymiarze międzydzielnicowym niewątpliwie wiąże się z kwestią jurysdykcji sądu konsystorskiego. Związek 
ten polegał w istocie na określeniu granic prawa do rozwodu w Polsce międzywojennej. Przepisy międzywyznaniowe wyznaczały te granice tak w byłej Kongresówce, jak i w województwach południowych. W województwach tych mieliśmy ponadto do czynienia $\mathrm{z}$ dodatkowym obostrzeniem - zakazem kolejnego małżeństwa po uzyskaniu rozwodu. W tym przypadku nie chodziło już o reglamentację prawa do rozwodu, ale o reglamentację prawa do małżeństwa. Podłożem tej reglamentacji były oczywiście dogmaty katolickie. Reglamentacja ta stanowi istotę przeszkody katolicyzmu.

W XIX w. przeszkody małżeńskie o podłożu religijnym odchodziły w niebyt. Małżeństwo podlegało procesowi sekularyzacji. Anachroniczność doktryny katolickiej w tym względzie była nie do przyjęcia nawet dla władz carskiej Rosji, która była przecież państwem wyznaniowym. W tym kontekście zdumiewa fakt, że przeszkoda katolicyzmu przetrwała $\mathrm{w}$ ramach systemu prawnego II Rzeczypospolitej, ba przetrwała nawet samą II Rzeczpospolitą. Kres jej położyła dopiero zmiana stosunków społeczno-politycznych w 1945 r., prowadząca do sekularyzacji prawa małżeńskiego w Polsce. Fakt ten najlepiej chyba unaocznia skalę zacofania II Rzeczypospolitej w sferze regulacji stosunków społecznych.

\author{
IMPEDIMENTUM CATOLICISMI IN THE LAW \\ OF SOUTHERN VOIVODSHIPS OF THE SECOND POLISH REPUBLIC
}

\title{
Summary
}

The focus of this paper is on the effects of the impediment of Catholic faith (impedimentum catolicismi) binding in Poland's southern voivodships after the country regained independence in 1918. Catholic faith was one of the marriage impediments under the Austrian civil code of 1811 (ABGB), and was grounded in the principle of insolubility of a Catholic marriage. It began with the provision of $\S 111$ of the ABGB, followed by the regulation contained in $\S 62$ and $\S 119$ and was complemented with decrees of 1814 and 1835. Under Austrian law, a Catholic marriage could not be dissolved by divorce.

The impediment of Catholic faith had consequently influenced legal relationships in interwar Poland during which Poland was a state of a non-uniform legal system, with laws of former partitioning states still binding in formerly occupied, but then already independent regions. However, the impediment of Catholic faith was only in force in the formerly Austrian part of partitioned Poland. This created certain confusion in the area of family law and resulted in development of divorce seeking migration to other parts of Poland where the impediment was not recognised. And yet, problems continued to remain as marriages concluded after a divorce obtained in another part of Poland were still, due to impedimentum catolicismo invalid. This situ- 
ation changed only in 1945 after the implementation of a unification of matrimonial law and resulting from it civil marriage.

\section{L'EMPÊCHEMENT DE CATHOLICISME PRÉVU PAR LE DROIT DES VOÏVODIES DU SUD DE LA II ${ }^{\mathrm{E}}$ RÉPUBLIQUE DE POLOGNE}

\section{Résumé}

L'objet des présentes réflexions sont les conséquences liées à l'empêchement de catholicisme (impedimentum catholicismi) en application après le recouvrement de l'indépendance par la Pologne. Il s'agit en l'occurrence d'un des empêchements au mariage, présent dans le code civil autrichien de 1811 (ABGB). L'empêchement de catholicisme trouve son bien-fondé dans le principe d'insolubilité du mariage catholique. Le point du départ pour les traits caractéristiques de l'empêchement est la dispotion du $\S 111$ de l'ABGB. Le règlement prévu au $\S 62$ et 119 joue également un rôle essentiel, le tout ayant été complété par les dispositions des décrets publiés par la chancellerie de la cour en 1814 et 1835.

Le droit autrichien de l'époque exclut le divorce dans le cas des mariages conclus entre les catholiques. L'empêchement de catholicisme en Pologne de l'entre-deuxguerres influencera les relations juridiques de manière particulière, compte tenu du système juridique en vigueur qui reste hétéroclite. Or, en fonction de la région, la législation de l'ancien État envahisseur sera en application. L'empêchement de catholicisme reste donc en vigueur uniquement dans cette partie de la Pologne qui appartenait auparavant à l'Autriche. Par conséquent, les relations entre les provinces tiennent compte des effets liés à la validité de l'empêchement de catholicisme, ce qui fait naître un chaos dans le domaine juridico-familial. Les possibilités de divorce limitées aux catholiques par le droit autrichien ont pour effet ce que l'on appelait les voyages de divorce, effectués vers les régions de l'État polonais où le divorce était admis. Toutefois, le mariage conclu après le divorce prononcé, restait null, étant donné l'empêchement de catholicisme. La jurisprudence de la Cour Suprême présentée dans la présente dissertation permet de se rendre compte de l'échelle des problèmes rencontrés dans le domaine juridico-familial et nés justement à cause de l'empêchement de catholicisme en vigueur après le recouvrement de l'indépendance par la Pologne. L'unification du droit du mariage en 1945, dans le cadre de laquelle le principe de la laïcité du mariage est entré en vigueur en Pologne, mettra finalement fin à cette situation. 
